NOTE

\title{
Efficacy of SYBR 14/propidium iodide viability stain for the amphibian chytrid fungus Batrachochytrium dendrobatidis
}

\author{
M. P. Stockwell* , J. Clulow, M. J. Mahony \\ School of Environmental and Life Sciences, University of Newcastle, Callaghan Drive, Callaghan, New South Wales 2308, \\ Australia
}

\begin{abstract}
The amphibian chytrid fungus Batrachochytrium dendrobatidis is a recently described pathogen that has been implicated as a causal agent in the global decline in amphibians. Research into its biology and epidemiology has frequently involved in vitro experimentation. However, this research is currently limited by the inability to differentiate between viable and inviable zoospores. Stains are frequently used to determine cell viability, and this study tested a 2-colour fluorescence assay for the detection and quantification of viable $B$. dendrobatidis zoospores. The results show that the nucleic acid stains SYBR 14 and propidium iodide are effective in distinguishing live from dead zoospores, and a protocol has been optimized for their use. This viability assay provides an efficient and reliable tool that will have applications in $B$. dendrobatidis challenge and amphibian exposure experiments.
\end{abstract}

KEY WORDS: Batrachochytrium dendrobatidis · Amphibian chytrid fungus · Viability · Stain · Zoospore

Resale or republication not permitted without written consent of the publisher

\section{INTRODUCTION}

The amphibian chytrid fungus Batrachochytrium dendrobatidis is a recently described microorganism belonging to the phylum Chytridiomycota. The Chytridiomycota are a group of aquatic heterotrophic fungi with zoosporangic thalli and discharge papillae that release motile flagellated zoospores (Barr 1990). They are generally biodegraders of cellulose, chitin and keratin, although some are pathogens of vascular plants and insects (Barr 1990). B. dendrobatidis is the first Chytridiomycota described that infects vertebrate hosts (Berger et al. 1998, Longcore et al. 1999). It infects the keratinized mouthparts of tadpoles and the outer keratinized epidermal layers of frogs, which can cause the fatal disease chytridiomycosis in susceptible species (Berger \& Speare 1998, Berger et al. 1998, Longcore et al. 1999). Chytridiomycosis has been implicated as a causal agent in the decline and extinction of amphibian populations worldwide (Laurance et al. 1996, Berger et al. 1998, Lips 2005, Skerratt et al. 2007).

Since the discovery of Batrachochytrium dendrobatidis, in vitro experimentation has played an important role in understanding its biology and epidemiology. Challenge assays have been used in the development of disinfectants and quarantine guidelines to prevent its spread (Johnson et al. 2003, Johnson \& Speare 2003, Webb et al. 2007, Mendez et al. 2008) as well as the identification of environmental tolerance limits (Piotrowski et al. 2004) and the effectiveness of host immune responses (Rollins-Smith et al. 2002a,b, 2003, Johnson \& Speare 2003, Harris et al. 2006, Woodhams et al. 2006a,b, Conlon et al. 2007, Woodhams et al. $2007 a, b, c)$.

Amphibian exposure experiments conducted in vitro have also investigated the effects of infection on the 
survivorship of different host species (Daszak et al. 2004, Blaustein et al. 2005, Garcia et al. 2006, Vazquez et al. 2009) and how this differs with host age (Lamirande \& Nichols 2002, Rachowicz \& Vredenburg 2004), body size (Carey et al. 2006), immune response (Woodhams et al. 2007a), fungal strain (Berger et al. 2005, Retallick \& Miera 2007) and fungal density (Carey et al. 2006). The outcome of infections has been investigated under different temperature regimes (Berger et al. 2004, Carey et al. 2006, Andre et al. 2008, Woodhams et al. 2008) and in the presence of environmental stressors (Parris \& Baud 2004, Garcia et al. 2006), competitors (Parris \& Cornelius 2004) and predators (Parris $\&$ Beaudoin 2004). However, this research is currently limited by the inability to confidently distinguish and quantify zoospore viability.

The viability of Batrachochytrium dendrobatidis zoospores in culture is difficult to determine and indices such as growth and motility are generally used. However, the use of these indicators requires observation over several weeks and an absence of growth and motility does not necessarily imply that a cell is inviable. Stains are frequently used to detect cell viability in microbiology, medical sciences and reproductive biology and they work by targeting cellular processes that change with cell death (Haugland 2002). The stains SYBR 14 and propidium iodide are nucleic acid stains that can provide a 2-colour fluorescence assay of cell viability based on their ability to penetrate cell membranes. The SYBR 14 stain passively diffuses through the membranes of all cells, binds to nucleic acids and fluoresces green with visible light excitation (Haugland 2002). Propidium iodide is a membraneimpermeable stain that can only penetrate cells when their membranes are permeabilized. Diffusion into dead and dying cells occurs as the regulation of membrane transport slows or cells lyse and the stain binds to nucleic acids making dead cells fluoresce red (Krishan 1975, Jones \& Senft 1985, Haugland 2002). This paper examines the efficacy of SYBR 14/propidium iodide stains in determining the viability of $B$. dendrobatidis zoospores.

\section{MATERIALS AND METHODS}

A Batrachochytium dendrobatidis isolate (strain Gibbo River-Llesueuri-00-LB1) was obtained from the Australian Animal Health Laboratory (AAHL) in Geelong, Victoria, and stored at $-80^{\circ} \mathrm{C}$, following the protocol developed by Boyle et al. (2003). For this experiment, a sample of $B$. dendrobatidis was thawed and then grown in $10 \mathrm{ml}$ culture flasks in TGhL liquid culture media (16 $\mathrm{g}$ tryptone, $2 \mathrm{~g}$ gelatin hydrolysate, $4 \mathrm{~g}$ lactose in $1 \mathrm{l}$ deionised water) at $22^{\circ} \mathrm{C}$ for $4 \mathrm{~d}$. A $1 \mathrm{ml}$ sample of the actively growing culture was transferred to a sterile culture plate containing TGhL agar (16 g tryptone, $2 \mathrm{~g}$ gelatin hydrolysate, $4 \mathrm{~g}$ lactose, $10 \mathrm{~g}$ bacteriological agar in 11 of deionised water) and allowed to grow at $22^{\circ} \mathrm{C}$ for $4 \mathrm{~d}$. Zoospores were then harvested by flooding the culture plate with $5 \mathrm{ml}$ of sterile distilled water and allowing it to stand for $1 \mathrm{~h}$. This zoospore suspension was then collected and used to test the efficacy of the viability stains and to optimize stain concentrations.

To test the efficacy of the stains differentiating between live and dead zoospores, half of the resulting zoospore suspension was heat treated in an oven at $47^{\circ} \mathrm{C}$ for $1 \mathrm{~h}$, in order to kill the zoospores (Johnson et al. 2003), while the other half was kept alive in a constant temperature room at $22^{\circ} \mathrm{C}$ for $1 \mathrm{~h}$. Mixtures of non-heat-treated and heat-treated zoospore concentrations (presumably live or dead respectively) were then made with $0,25,50,75$ or $100 \%$ heat-treated zoospore suspension.

In order to confirm that the heat treatment had killed the zoospores and that those identified as dead in this experiment were non-viable, a growth experiment was conducted. A $100 \mu \mathrm{l}$ sample of each previously prepared zoospore suspension was grown in $900 \mu \mathrm{l}$ of TGhL liquid media in a 48-well flat-bottom culture plate, with each concentration replicated 8 times. Plates were incubated at $22^{\circ} \mathrm{C}$ for $7 \mathrm{~d}$. The amount of growth in each well was then sampled by counting the number of zoosporangia in an ocular frame $(76 \times$ $42 \mu \mathrm{m})$ at $200 \times$ magnification under an inverted microscope (Axiovert 35, Zeiss).

SYBR 14 and propidium iodide (Molecular Probes) were obtained as a sperm viability kit (catalogue number L-7011). The SYBR 14 dye was supplied as a $1 \mathrm{mM}$ solution in dimethyl sulfoxide (DMSO) and was diluted 1:100 with $1 \mathrm{X}$ tris-buffered saline (TBS, pH 7.4). The propidium iodide was supplied as an aqueous $2.4 \mathrm{mM}$ solution and was used undiluted. To stain zoospores, $50 \mu \mathrm{l}$ of each suspension mixture was added to 8 wells in a 96-well plate and left for $20 \mathrm{~min}$ so that zoospores settled to the bottom of the well. A $6 \mu \mathrm{l}$ sample of the diluted SYBR 14 dye was added to each well and allowed to incubate at room temperature for $10 \mathrm{~min}$. A total of $2 \mu$ l of undiluted propidium iodide was then added to each and again left to incubate at room temperature for $10 \mathrm{~min}$. To quantify the stained zoospores, the number of zoospores fluorescing red and green within an ocular frame $(26 \times 17 \mu \mathrm{m})$ were counted at $400 \times$ magnification under an inverted microscope with mercury lamp fluorescence (HBO $50 \mathrm{~W} / \mathrm{AC}$, Osram) and blue light 450 to $490 \mathrm{~nm}$ excitation (450 to $490 \mathrm{~nm}$ exciter filter, FT $510 \mathrm{~nm}$ chrome beam splitter, LP $520 \mathrm{~nm}$ barrier filter). The percentage of zoospores that were fluorescing red was then deter- 
mined. A chi-square goodness-of-fit test was used to determine whether the observed percentage of red zoospores was significantly different from the expected percentage of heat-treated and presumably dead zoospores in each suspension mixture.

Finally, in addition to determining the efficacy of these stains, the stain concentrations that allowed the greatest differentiation between red and green were identified through a visual assessment of fluorescent intensity with different concentration combinations of SYBR 14 and propidium iodide. Cell monolayers were created by growing $25 \mu$ of the actively growing culture in $175 \mu \mathrm{l}$ of fresh liquid media in each well of a 96-well plate at $22^{\circ} \mathrm{C}$ for $7 \mathrm{~d}$. Following growth, $150 \mu \mathrm{l}$ of active culture media was removed from each well, leaving a $50 \mu$ layer of culture media covering the surface. Combinations of SYBR $14(2,4,6,8$ and $10 \mu l)$ and propidium iodide $(1,2$ and $3 \mu \mathrm{l})$ volumes were each added to 8 wells, with SYBR 14 added first and left to incubate for $10 \mathrm{~min}$, and then propidium iodide was added followed by another 10 min incubation period. Each well was then observed under an inverted microscope at $400 \times$ magnification and were given scores out of 5 for intensity of green and red zoospore fluorescence and the intensity of any background fluorescence ( $0=$ no fluorescence; $5=$ bright fluorescence). The concentration combination that provided the highest average zoospore fluorescence and the lowest average background fluorescence was considered optimal.

\section{RESULTS}

The growth experiment confirmed that heat treatment was effective in killing zoospores by demonstrating that no growth occurred in the $100 \%$ heat-treated suspension (Fig. 1). The number of zoospores counted following growth in the 0 to $75 \%$ heat-treated mixtures also approximated the proportion of cells added to

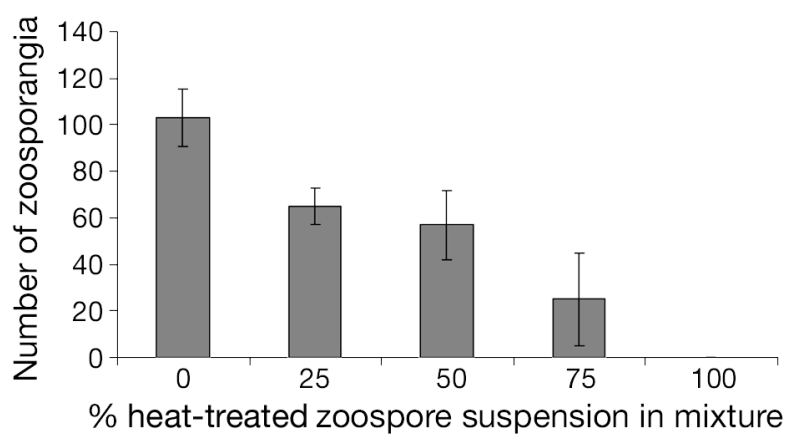

Fig. 1. Batrachochytrium dendrobatidis. Mean $( \pm \mathrm{SE})$ zoosporangia counted after $7 \mathrm{~d}$ growth at $22^{\circ} \mathrm{C}$ in zoospore suspension mixture containing various proportions of heat-treated (and presumably dead) zoospores each group, relative to one another (Fig. 1). In addition, all motile zoospores were found to stain green and motility was observed in stained cells for $4 \mathrm{~h}$, at which point the experiment was terminated. No motile zoospores were seen to stain red.

Zoospore mixtures containing no heat-treated zoospores $(0 \%$ heat-treated) still stained $12 \pm 6 \%$ of zoospores red (average $\pm \mathrm{SE}$ ) and this was assumed to be due to the collection of some dead zoospores from the culture plate at the harvesting stage. Therefore, the number of red zoospores counted in each well of the remaining mixtures was corrected for the $12 \%$ of dead zoospores in the original zoospore suspension. Following this correction, the mean proportions of red zoospores counted in each well were similar to the proportion of heat-treated zoospores added to the mixtures (Table 1). A chi-square goodness of fit test determined that there was no significant difference between the observed and expected proportions of red zoospores in each group (25\% mixture $\chi^{2}{ }_{7}=3.67 ; 50 \%$ mixture $\chi^{2}{ }_{7}=12.20 ; 75 \%$ mixture $\chi^{2}{ }_{7}=6.00$ ), indicating that the stains were accurately distinguishing live from dead zoospores.

The testing of differing stain concentrations established that optimal staining was achieved with $6 \mu$ l of the 1:100 diluted SYBR 14 and $2 \mu$ of undiluted propidium iodide. These concentrations produced brightly stained zoospores that were clearly distinguishable as either green or red with little background fluorescence (Fig. 2). Incubation times of $10 \mathrm{~min}$ between the additions of each stain were found to be appropriate for achieving optimal stain differentiation.

\section{DISCUSSION}

The use of stains to target cellular processes that change with cell death can resolve the uncertainty associated with determining cell viability. The results of the present study show that live and dead Batrachochytium dendrobatidis zoospores can be differenti-

Table 1. Mean proportion $( \pm \mathrm{SD})$ of red zoospores counted following cell viability staining of heat-treated zoospore suspension mixtures where $12 \%$ of red zoospores were disregarded from each well to account for dead zoospores collected at harvesting

\begin{tabular}{|cc|}
\hline $\begin{array}{c}\text { \% of heat-treated } \\
\text { zoospores }\end{array}$ & $\begin{array}{c}\text { Mean \% of red } \\
\text { zoospores }( \pm \text { SD) }\end{array}$ \\
\hline 0 & 0 \\
25 & $28( \pm 13)$ \\
50 & $62( \pm 14)$ \\
75 & $77( \pm 10)$ \\
100 & $100( \pm 0)$ \\
\hline
\end{tabular}




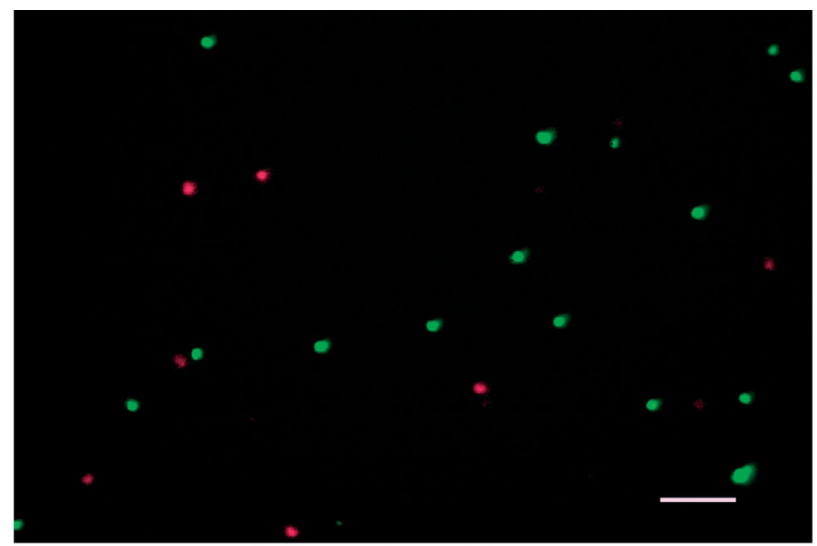

Fig. 2. Batrachochytrium dendrobatidis. Photomicrograph of zoospores following cell viability staining with SYBR 14 and propidium iodide. Live zoospores stain green; dead zoospores stain red. Scale bar $=20 \mu \mathrm{m}$

ated with the use of a SYBR 14/propidium iodide 2-colour fluorescent assay and a protocol has been optimized for this use. This assay provides a simple and time-efficient tool that will assist in the quantification of viable zoospores and will have a range of applications.

The availability of a viability stain for Batrachochytium dendrobatidis zoospores will prove particularly valuable for assessing the outcome of challenge assays. The capacity to distinguish live from dead cells following exposure to a stressor will allow survival rates to be quantified for comparison between treatments. This method removes the need to rely upon indices of cell viability such as growth and motility and will result in more reliable outcomes. The quantification of viable zoospores may also prove useful in amphibian exposure experiments that require zoospores to be harvested from actively growing cultures. Determining the proportion of viable, and therefore infective, zoospores harvested prior to exposures will allow the desired dosage to be calculated. It will also enhance repeatability in future studies and may improve the accuracy of infection outcome predictions. This will be particularly important in experiments exposing amphibians to multiple batches, strains or isolates of $B$. dendrobatidis, where differences in the proportion of viable zoospores in each harvest may confound results.

In addition to distinguishing live from dead cells for quantification, staining of live zoospores may also provide novel ways of observing motility, dispersal, growth and survival. SYBR 14 binds to nucleic acids and fluoresces, without interfering with cellular processes, and this study suggests observation of live zoospores could be made for at least $4 \mathrm{~h}$ following staining. However, because both SYBR 14 and propidium iodide are nucleic acid stains, caution should be taken when utilizing these stains in situations where
DNA may be disrupted or denatured, such as in the presence of alcohols or oxidizing agents (Overton \& McCoy 1994, Phe et al. 2007). Damage or changes to the structural integrity of nucleic acids will limit the stain's binding ability, resulting in reduced fluorescent signal (Hamilton et al. 1980, Overton \& McCoy 1994, Phe et al. 2007). The inclusion of internal positive controls in experiments will allow these reduced signals to be identified.

Despite this limitation, the use of viability stains in Batrachochytium dendrobatidis research will improve the efficiency, reliability and repeatability of future in vitro experimental outcomes. The identification of methods to control the spread and impact of B. dendrobatidis infection is essential for the prevention and reversal of amphibian declines and the availability of the SYBR 14/propidium iodide viability assay can facilitate this process.

Acknowledgements. We thank Donna Boyle for supplying the Batrachochytium dendrobatidis isolate and Natasha Czarny for providing guidance on staining techniques. This work was supported by the Kooragang Wetland Rehabilitation Project and the Barker Family Scholarship.

\section{LITERATURE CITED}

Andre SE, Parker J, Briggs CJ (2008) Effect of temperature on host response to Batrachochytrium dendrobatidis infection in the mountain yellow-legged frog (Rana muscosa). J Wildl Dis 44:716-720

Barr DJS (1990) Phylum Chytridiomycota. In: Marguilis L, Cotliss JO, Melkonian M, Chapman DJ (eds) Handbook of Protoctista. Jones and Bartlett, Boston, MA, p 454-466

Berger L, Speare R (1998) Chytridiomycosis: a new disease of wild and captive amphibians. ANZCCART Newsl 11:1-3

- Berger L, Speare R, Daszak P, Green DE and others (1998) Chytridiomycosis causes amphibian mortality associated with population declines in the rain forests of Australia and Central America. Proc Natl Acad Sci USA 95:9031-9036

Berger L, Speare R, Hines H, Marantelli G and others (2004) Effect of season and temperature on mortality in amphibians due to chytridiomycosis. Aust Vet J 82:434-440

Berger L, Marantelli G, Skerratt LF, Spear R (2005) Virulence of the amphibian chytrid fungus Batrachochytrium dendrobatidis varies with strain. Dis Aquat Org 68:47-50

Blaustein AR, Romansic JM, Scheessele EA, Han BA, Pessier AP, Longcore JE (2005) Interspecific variation in susceptability of frog tadpoles to the pathogenic fungus Batrachochytrium dendrobatidis. Conserv Biol 19:1460-1468

Boyle DG, Hyatt AD, Daszak P, Berger L and others (2003) Cryo-archiving of Batrachochytrium dendrobatidis and other chytridiomycetes. Dis Aquat Org 56:59-64

Carey C, Bruzgul JE, Livo LJ, Walling ML and others (2006) Experimental exposures of boreal toads (Bufo boreas) to a pathogenic chytrid fungus (Batrachochytrium dendrobatidis). EcoHealth 3:5-21

Conlon JM, Woodhams DC, Raza H, Coquet L and others (2007) Peptides with differential cytolytic activity from skin secretions of the lemur leaf frog Hylomantis lemur (Hylidae: Phyllomedusinae). Toxicon 50:498-506

Daszak P, Strieby A, Cunningham AA, Longcore JE, Brown 
CC, Porter D (2004) Experimental evidence that the bullfrog (Rana catesbeiana) is a potential carrier of chytridiomycosis, an emerging fungal disease of amphibians. Herpetol J 14:201-207

> Garcia TS, Romansic JM, Blaustein AR (2006) Survival of three species of anuran metamorphs exposed to UV-B radiation and the pathogenic fungus Batrachcochytrium dendrobatidis. Dis Aquat Org 72:163-169

Hamilton VT, Habbersett MC, Herman CJ (1980) Flow microfluotometric analysis of cellular DNA: critical comparison of mithramycin and propidium iodide. J Histochem Cytochem 28:1125-1128

Harris RN, James TY, Lauer A, Simon MA, Patel A (2006) Amphibian pathogen Batrachochytrium dendrobatidis is inhibited by the cutaneous bacteria of amphibian species. EcoHealth 3:53-56

Haugland RP (ed) (2002) Handbook of fluorescent probes and research products. Molecular Probes, Leiden

> Johnson ML, Speare R (2003) Survival of Batrachochytrium dendrobatidis in water: quarantine and disease control implications. Emerg Infect Dis 9:922-925

> Johnson ML, Berger L, Philips L, Speare R (2003) Fungicidal effects of chemical disinfectants, UV light, desiccation and heat on the amphibian chytrid Batrachochytrium dendrobatidis. Dis Aquat Org 57:255-260

Jones KH, Senft JA (1985) An improved method to determine cell viability by simultaneous staining with fluorescein diacetate - propidium iodide. J Histochem Cytochem 33:77-79

Krishan A (1975) Rapid flow cytofluorometric analysis of mammalian cell cycle by propidium iodide staining. J Cell Biol 66:188-193

Lamirande EW, Nichols DK (2002) Effects of host age on susceptability to cutaneous chytridiomycosis in blue-andyellow poison dart frogs (Dendrobates tinctorius). In: McKinnell RG, Carlson DL (eds) Proceeding of the Sixth International Symposium on the Pathology of Reptiles and Amphibians University of Minnesota Printing Services, St. Paul, MN, p 3-13

- Laurance WF, McDonald KR, Speare R (1996) Epidemic disease and the catastrophic decline of Australian rain forest frogs. Conserv Biol 10:406-413

Lips KR (2005) Amphibian population declines in Latin America: a synthesis. Biotropica 37:222-226

Longcore JE, Pessier AP, Nichols DK (1999) Batrachochytrium dendrobatidis gen. et sp. nov., a chytrid pathogenic to amphibians. Mycologia 91:219-227

Mendez D, Webb R, Berger L, Speare R (2008) Survival of the amphibian chytrid fungus Batrachochytrium dendrobatidis on bare hands and gloves: hygiene implications for amphibian handling. Dis Aquat Org 82:97-104

Overton WR, McCoy PJ (1994) Reversing the effect of formalin on the binding of propidium iodide to DNA. Cytometry 16:351-356

Parris MJ, Baud DR (2004) Interactive effects of a heavy metal and chytridiomycosis on gray treefrog larvae (Hyla chrysoscelis). Copeia 2004:344-350

> Parris MJ, Beaudoin JG (2004) Chytridiomycosis impacts predator-prey interactions in larval amphibian communities. Oecologia 140:626-632

Parris MJ, Cornelius TO (2004) Fungal pathogen causes competitive and developmental stress in larval amphibian communities. Ecology 85:3385-3395

Editorial responsibility: Andrew Cunningham, London, UK
Phe MH, Dossot M, Guilloteau H, Block JC (2007) Highly chlorinated Escherichia coli cannot be stained by propidium iodide. Can J Microbiol 53:664-670

> Piotrowski JS, Annis SL, Longcore JE (2004) Physiology of Batrachochytrium dendrobatidis, a chytrid pathogen of amphibians. Mycologia 96:9-15

- Rachowicz LJ, Vredenburg VT (2004) Transmission of Batrachochytrium dendrobatidis within and between amphibian life stages. Dis Aquat Org 61:75-83

Retallick RW, Miera V (2007) Strain differences in the amphibian chytrid Batrachochytrium dendrobatidis and non-permanent, sub-lethal effects of infection. Dis Aquat Org 75:201-207

> Rollins-Smith LA, Carey C, Longcore JE, Doersam JK, Boutte A, Bruzgal JE, Conlon JM (2002a) Activity of antimicrobial skin peptides from ranid frogs against Batrachochytrium dendrobatidis, the fungus associated with global amphibian declines. Dev Comp Immunol 26:471-479

Rollins-Smith LA, Doersam JK, Longcore JE, Taylor SK, Shamblin JC, Carey C, Zasloff MA (2002b) Antimicrobial peptide defenses against pathogens associated with global amphibian declines. Dev Comp Immunol 26:63-72

Rollins-Smith LA, Carey C, Conlon JM, Reinert LK and others (2003) Activities of temporin family peptides against the chytrid fungus (Batracochytrium dendrobatidis) associated with global amphibian declines. Antimicrob Agents Chemother 47:1157-1160

Skerratt LF, Berger L, Speare R, Cashins S and others (2007) Spread of chytridiomycosis has caused the rapid global decline and extinction of frogs. EcoHealth 4:125-134

- Vazquez VM, Rothermel BB, Pessier AP (2009) Experimental infection of North American plethodontid salamanders with the fungus Batrachochytrium dendrobatidis. Dis Aquat Org 84:1-7

Webb R, Mendez D, Berger L, Spear R (2007) Additional disinfectants effective against the amphibian chytrid fungus Batrachochytrium dendrobatidis. Dis Aquat Org 74: $13-16$

Woodhams DC, Rollins-Smith LA, Carey C, Reinert L, Tyler MJ, Alford RA (2006a) Population trends associated with skin peptide defenses against chytridiomycosis in Australian frogs. Oecologia 146:531-540

> Woodhams DC, Voyles J, Lips KR, Carey C, Rollins-Smith LA (2006b) Predicted disease susceptability in a Panamanian amphibian assemblage based on skin peptide defenses. J Wildl Dis 42:207-218

Woodhams DC, Ardipraja K, Alford RA, Marantelli G, Reinert LK, Rollins-Smith LA (2007a) Resistance to chytridiomycosis varies among amphibian species and is correlated with skin peptide defenses. Anim Conserv 10:409-417

Woodhams DC, Rollins-Smith LA, Alford RA, Simon MA, Harris RN (2007b) Innate immune defenses of amphibian skin: antimicrobial peptides and more. Anim Conserv 10: $425-428$

> Woodhams DC, Vredenburg VT, Simon MA, Billheimer D and others $(2007 \mathrm{c})$ Symbiotic bacteria contibute to innate immune defenses of the threatened mountain yellowlegged frog, Rana muscosa. Biol Conserv 138:390-398

> Woodhams DC, Alford RA, Briggs CJ, Johnson M, RollinsSmith LA (2008) Life-history trade-offs influence disease in changing climates: strategies of an amphibian pathogen. Ecology 89:1627-1639

Submitted: June 25, 2009; Accepted: October 12, 2009

Proofs received from author(s): January 11, 2010 